„Kwartalnik Filmowy” nr 115 (2021)

ISSN: 0452-9502 (Print) ISSN: 2719-2725 (Online)

https://doi.org/10.36744/kf.878

(c) Greative Commons BY-NC-ND 4.0

Beata Kosińska-Krippner

Instytut Sztuki, Polska Akademia Nauk

https://orcid.org/oooo-0001-8096-9708

\title{
Avi Mograbi. Gonzo-dokumenty
}

\section{Słowa kluczowe:}

Avi Mograbi; gonzo-dokument; strategia autorska;

kino izraelskie; konflikt izraelsko-

-palestyński; prawa człowieka

\begin{abstract}
Abstrakt
Urodzony w 1956 r. Avi Mograbi uchodzi za jednego z najważniejszych, ale też najbardziej kontrowersyjnych izraelskich filmowców swojego pokolenia. Realizuje filmy polityczne, w których konsekwentnie krytycznie ocenia kondycję społeczeństwa Izraela i politykę tego kraju, zwłaszcza wobec Palestyny. Realizując filmy na pograniczu fikcji i faktu, twórca ten wypracował wyrazistą poetykę autorską; jego filmy funkcjonują głównie jako dokumenty i do tej normy stylistycznej on sam się odnosi, ale robi to na własnych zasadach. Mograbi eksperymentuje z językiem filmowym w kontekście rozwiązań narracyjnych i warsztatowo-stylistycznych. Ze względu na specyfikę wykorzystywania dokumentalności w dziełach Mograbiego autorka skojarzyła metodę twórczą reżysera z gonzo-dziennikarstwem i na przykładzie wybranych filmów przeanalizowała konkretne jej realizacje. Szczególna strategia reżysera rzuca światło na naturę „rzeczywistości” w filmach dokumentalnych i ujawnia sposób, w jaki rzeczywistość determinuje zarówno tworzenie filmów, jak i samego filmowca.
\end{abstract}


Nic nie wiesz o Afganistanie? Winić za to trzeba śmierć filmu dokumentalnego

Charlotte Raven ${ }^{1}$

Hybrid Reality: Kiedy dokument i fikcja łacza się, by stworzyć lepsza prawde

Chuleenan Svetvilas ${ }^{2}$

Dokument to film niefabularny, który przekazuje widzom prawdę o sprawie. A jeśli robi to skutecznie, nie ma znaczenia, jaki styl lub forma zostanie użyta.

Jonathan Caouette ${ }^{3}$

\section{Giez w Ziemi Świętej}

Urodzony w 1956 r. Avi Mograbi uchodzi za jednego z najważniejszych, najbardziej innowacyjnych, ale też kontrowersyjnych izraelskich filmowców swego pokolenia. Niektórzy mówią o nim „reżyser giez”4 , bo natrętnie brzęczy i boleśnie kłuje, realizując filmy konsekwentnie krytykujące politykę Izraela zwłaszcza wobec Palestyny. Konflikt między tymi krajami, a także wpływ przemocy na jednostkę to główne tematy jego twórczości. Natarczywe w formie i bezkompromisowe w treści filmy Mograbiego badają paradoksy społeczeństwa izraelskiego i szerzej nierówności społeczno-politycznych. Samo określenie "giez" można odnieść do pojęcia, którego użył Platon w Obronie Sokratesa, kiedy jego nauczyciel miał porównywać społeczność ateńską do ospałego konia, a siebie do owada, który żądli, by nie dopuścić do jej zgnuśnienia ${ }^{5}$. Tak więc ten giez to osoba, która ingeruje w status quo wspólnoty, stawiając nowe, potencjalnie niepokojące pytania, zwykle kierowane do władz. Taką niewygodną postacią jest Mograbi, który z żydowska tożsamościa państwa izraelskiego radzi sobie za pomoca oryginalnego autorskiego podejścia. Walczy z nia, śmieje się z niej, trzyma się od niej z daleka, analizuje ja, ale nie wyrzeka się jej. Jako "lewicowiec" stoi po przeciwnej stronie spektrum politycznego niż większość społeczeństwa. W rezultacie izraelscy widzowie "karza" go ostentacyjnym brakiem zainteresowania jego filmami $^{6}$. Z drugiej strony uniwersalne wątki polityczne i oryginalność formalna jego twórczości wzbudziły odzew za granica, o czym świadczą reakcje widzów i liczne nagrody międzynarodowe. Mograbi często pojawia się w swoich filmach, zarówno jako reżyser, quasi-narrator, jak i zatroskany obywatel, starający się zrozumieć, czego jest świadkiem. Twórca ten - o silnej osobowości, zdeterminowany, kreatywny, pełen pasji, empatii i humoru - jest znany z zaangażowania na rzecz sprawiedliwości społecznej, kulturowej i politycznej na Bliskim Wschodzie. Jako naoczny świadek konfliktu aktywnie działa w Breaking the Silence, organizacji dokumentującej zeznania izraelskich żołnierzy, którzy służyli na okupowanych terytoriach palestyńskich. W latach 2001-2007 w ramach projektu Anti-Occupation Film Club przy Filmotece w Tel Awiwie prezentował filmy palestyńskie - ale nie tylko, bo także z innych krajów - dotyczące okupacji ${ }^{7}$. Pokazy te pozwalały Izraelczykom przyjąć punkt widzenia Palestyńczyków, a dyskusje po seansie stanowiły okazję, by zaprotestować przeciwko okupacji. Reżyser jest członkiem Komitetu Wsparcia w działającym od 2009 r. Russell Tribunal on Palestine. 
Mograbiego interesuje związek między twórczością artystyczną a zaangażowaniem politycznym, zastanawia się nad rolą filmowca jako aktywisty oraz nad realizowaniem dokumentów jako metodą oporu politycznego i walki o sprawiedliwość społeczna ${ }^{8}$. Tworzy filmy o przenikaniu się tego, co osobiste, z tym, co polityczne. Staram się nie robić różnicy między wydarzeniami publicznymi a moim życiem osobistym. Z pewnościa wielu moich rodaków uważa okupację terytoriów palestyńskich za nie do przyjęcia, tak jak ja. Ale nie pozwalaja, aby ten problem polityczny wkroczyt w ich życie, nie robia nic, aby to zmienić lub wziać na siebie odpowiedzialność.

\section{Izraelski Stańczyk w masce szlemiela}

Mograbi, pojawiając się w swoich filmach, staje się ich twarzą jego osoba stanowi swoistą rękojmię przekazu. Trzeba jednak pamiętać, że reżyser użycza swego wizerunku jedynie wykreowanej personie o tym samym nazwisku. Będąc gzem na wzór Sokratesa, przyjmuje też (chociaż sam nigdy tego nie wyartykułował) jego metodę stymulacji. Mimo że niejako dominuje nad rozmówcami i odbiorcami, do pewnego stopnia kreując i kontrolując całą filmowaną sytuację, to jednak przybiera maskę prostaczka i sprawnie posługuje się mądrą ironią by - niczym starożytny filozof - stać się akuszerem nie tylko myśli w ogóle, ale też przemyśleń dotyczących spraw bardzo konkretnych. Zwracając się często wprost do kamery, Mograbi nie przemawia i nie poucza, wprowadza jedynie - za pomocą oryginalnej formy - intelektualny i moralny niepokój, skłania widzów do kwestionowania własnych poglądów. Najczęściej drwi, ironizuje, mówiąc przy tym o sprawach bolesnych czy tragicznych. Jest błaznem politycznym. Można go przyrównać do słynącego z ciętego dowcipu polskiego Stańczyka, symbolu prawdy. Tak jak on, Mograbi surowo ocenia decyzje polityczne rządzących, społeczeństwu zaś nie szczędzi gorzkich słów. Jego metoda tylko pozornie przypomina tę stosowaną przez Michaela Moore'a (krytyka globalizacji, korporacji i manipulacji informacją); choć Moore pojawia się przed kamerą jako zwykły obywatel poszukujący prawdy, to jednak prezentuje fakty i dowody zestawione bardzo tendencyjnie (inkrustowane nieprawdziwymi doniesieniami) i zaciera ślady autokreacji przed kamerą. Reżyser ten prezentuje siebie jako obrońcę uciśnionych i ostentacyjnie odgrywa rolę prowokatora. W przeciwieństwie do niego Mograbi ma tendencję do internalizowania sprzeczności, które odkrywa i (...) przedstawia siebie jako postać mniej heroiczna, a bardziej jako uroczego szlemiela ${ }^{10}$ (filmy kończą się zazwyczaj porażką przedsięwzięć „Mograbiego") ${ }^{11}$.

Potrafi śmiać się z siebie, jednocześnie bardzo poważnie traktując podejmowane tematy ${ }^{12}$. We wczesnych filmach grana przez reżysera autorefleksyjna postać filmowca bardziej przypomina Rossa McElwee z jego autobiograficznych dokumentów dotykających kwestii politycznych lub filozoficznych czy alter ego Nanniego Morettiego (z Dziennika intymnego /Caro Diario/, 1993), który pojawia się we własnych filmach jako postać swobodnie nawiązująca do niego samego ${ }^{13}$. Wymowa filmów Mograbiego jest często gorzka i pesymistyczna, ale zawsze są one przesiąknięte sarkastycznym humorem, którego klarowność sprawia, że można je traktować jako swoiste narzędzie do badania izraelskiej rzeczywistości, odsłaniające jej zakłamanie i sprzeczności. Humor stanowi dla reżysera kontrbroń, gdy filmuje swoich wrogów. Natychmiast też ujawnia konstrukcję zawartej w tych 
filmach fikcji (pozwala personie Mograbiego wchodzić w nią i z niej wychodzić), wydobywa złożoność rzeczywistości, co wraz z konfesyjnym tonem wypowiedzi staje się sposobem na usytuowanie jego politycznej twórczości poza obrębem kina wojującego $^{14}$ i nadaje jej wymiar uniwersalny.

\section{Uczciwość dokumentalisty}

Mograbi zbiera i nagrywa materiał na interesujący go temat, prowadzi z nim w swoisty dialog, po czym znajduje dla niego formę (czasem już na stole montażowym). Pomysły formalne rodzą się w procesie powstawania filmu, bywa że przypadkiem. Nawet jeśli Mograbi ma na początku określoną koncepcję, to najczęściej efekt końcowy diametralnie od niej odbiega. Reżyser często stwierdza, że dziś, w obliczu mnogości „,alternatywnych faktów” i fałszywych wiadomości, od dokumentalisty powinno się wymagać nie obiektywizmu, ale uczciwości ${ }^{15}$. To ważna deklaracja, mająca wpływ zarówno na treść, jak i formę jego filmów. Trudno w dokumencie o obiektywizm, skoro każdy ma swoją „prawdę” (zależną od dystansu - dosłownie i w przenośni), ale uczciwość - rozumiana jako proces - ma w sobie jednoznaczność, jest bowiem dążeniem. Mograbi kieruje się dość prostą dewizą: Filmy dokumentalne nie moga przywrócić prawdy. Kiedy ktoś robi film oparty na prawdziwej historii, nie oznacza to, że uchwycił ja w całości. Pomiędzy rzeczywistościa a widzem stoi umyst filmowca $i$ on decyduje o tym, jak należy tę historię opowiedzieć. Tak jak wtedy, gdy opowiadamy, co nam się przydarzyło, chociaż nie do końca odpowiada to faktom. Tak samo jest z wiadomościami - ktoś decyduje, o czym się mówi i jak ${ }^{16}$. Zobowiązania twórcy wobec prawdy i odpowiedzialności pozostają jednak w mocy - jego uczciwość wciąż jest istotna. Przy czym Mograbi w żadnym razie nie chciałby, aby filmowcy odczuwali presję trzymania się faktów w sposób staroświecki i musieli rezygnować z kreatywności czy wyobraźni ${ }^{17}$, chociaż zapewnia też, że w jego filmach nie zobaczymy czegoś, co się naprawdę nie wydarzyło. Kiedy w 1994 r. realizował The Reconstruction (The Danny Katz Murder Case) o skazaniu pięciu Arabów za zabicie w 1983 r. 15-letniego chłopca żydowskiego, włożył dużo energii w to, by - dysponując ogromną ilością materiałów - przedstawić prawdę i uniknąć manipulacji faktami. Później powiedział: To opowieść o życiu i śmierci, bardzo się starałem nie powiedzieć czegoś, czego nie byłem całkowicie pewien. Zajęło mi trochę czasu, zanim zrozumiałem, że niezależnie od podejmowanych przeze mnie wysiłków skala manipulacji jest ogromna. Publiczność może liczyć tylko na uczciwość twórcy. Cokolwiek robitem, manipulowałem ${ }^{18}$. Dlatego realizując kolejny film (How I Learned to Overcome My Fear and Love Arik Sharon, 1997), postanowił do niego „wejśćc", co potem stało się jego zwyczajem.

\section{Strategia „muchy w zupie”}

Podczas kręcenia filmów Mograbi toczy wewnętrzną walkę pomiędzy artystą i dobrym gawędziarzem a twórcą politycznie zaangażowanym. Realizując dokumenty w Izraelu, Mograbi spokojnie przygląda się swemu krajowi, mentalnie dystansując się wobec większości rodaków. Natomiast podczas konfrontacji z żołnierzami na terytoriach okupowanych traci spokój - beszta ich, wymyśla im. Mitchell Miller dostrzega tu swobodną inspirację zarówno amerykańskim kinem bezpośrednim, zwłaszcza postawą Roberta Drew wobec rozwoju postaci (wyko- 
rzystanie „struktury kryzysowej”, czyli poszukiwanie wcześniejszych kryzysów, które pozwolą ujawnić charakter postaci), jak i cinéma-vérité Jeana Roucha (wywoływanie kryzysu, by postać przetestować). Obdarzony dużą wrażliwością społeczną Mograbi wyjaśnia swoje (sfilmowane) wybuchy złości jako spowodowaną sytuacją utratę kontroli nad sobą - przyznaje przy tym, że takie sceny doskonale oddają charakter konfliktu izraelsko-palestyńskiego. Miller ma jednak rację, że ta pełna pasji postawa reżysera opiera się na bardzo spójnych przekonaniach politycznych i artystycznych. Na uwagę dziennikarza, że bardzo się angażuje w niektóre sytuacje i nie utrzymuje dystansu typowego dla wielu dokumentalistów, Mograbi odpowiada: To zawsze jest dylemat dla twórców filmów dokumentalnych, którzy wychowali się na stylu zwanym mucha na ścianie: "Obserwujemy, zbieramy, nie wpływamy”. Przede wszystkim pojęcie obiektywności jest znieksztatceniem tego, co rzeczywiście się dzieje; każda z sytuacji, jakakolwiek by była, stanowi reakcje na obecność kamery, w sposób jawny lub nie. (...) Nie ma czegoś takiego jak przezroczysta kamera i nie chcę kontynuować tej farsy. Jestem tutaj, a moja obecność wptywa na to, co robisz. Po drugie, wszystkie moje filmy opieraja sie na tematach, które mnie niepokoja i angażuja, nie sądze więc, że powinienem być mniej aktywny, ponieważ filmuję. Staram się nie narzucać regut swoim zachowaniom, dlatego kiedy jestem zmuszony zareagować, robię to, tyle że persona w filmie to nie ja sam. Używam swojego wizerunku, ale to nie sa w zupetności moje dylematy. Rozstrzygajac je, zgłębiam temat. Jeśli niektórzy widza siebie jako muchę na ścianie, ja widzę siebie jako muchę w zupie! To zaangażowanie absolutne ${ }^{19}$.

Filmy Mograbiego nawiązują do stylu dokumentów partycypacyjnych, jako że filmowiec inscenizuje w nich swą autorską podmiotowość. Przypomina to trochę sytuację z Wywiadu (Intervista, 1987), w którym Federico Fellini reżyseruje nagranie rozmowy przeprowadzonej z nim przez fikcyjną japońską ekipę filmową. To oczywiście żart, kpina z popkultury i żurnalistów, a także przykład manipulacji własną historia, do której prawo ma tylko sam reżyser. Twórczość Izraelczyka budzi też skojarzenia z niektórymi filmami Wernera Herzoga. Mograbi nie opowiada o sobie (a przynajmniej nie tylko), lecz w jawny sposób przefiltrowuje obserwowane wydarzenia przez własną wrażliwość, system wartości i przekonania, bo tak (w jego odczuciu) jest uczciwiej, niż gdyby udawał obiektywizm (zawsze pozorny). W interesujący i często zabawny sposób tworzy paralele między sobą a społeczeństwem. Jest centralną postacią większości swoich filmów, twórcą i motorem wielu sytuacji, czasem obserwatorem i uczestnikiem wydarzeń, elementem aktywnym i katalitycznym swojej twórczości ${ }^{20}$. Jego kamera jest zawsze częścią opowieści (fabuły).

\section{Hybrydy}

Mary Lea Bandy definiowała film dokumentalny jako poszukiwanie prawdy lub reprezentacji rzeczywistości, przeszłej i teraźniejszej. Mówiła: Reżyser może do tego dą̇yć na wiele sposobów - używając technik eksperymentalnych, materiałów archiwalnych $i$ zdjęć, wywiadów z historykami, zdjęć vérité, animacji i nie tylko. Nie ma jednej metody ${ }^{21}$. Trzeba się z nią zgodzić, że dokument jest formą hybrydowa, ale należy też dodać, że jego hybrydowość, mniej więcej od połowy lat 90. XX w., wraz ze wzmacnianiem się tendencji do łączenia sfery prywatnej z publiczna, staje się coraz bardziej widoczna, ostentacyjna, czasem wręcz subwersywna. Mograbi uznał, że 
skoro większość filmów dokumentalnych jest reżyserowana lub zawiera manipulacje ${ }^{22}$, to - aby uwiarygodnić przekaz - uczciwiej jest to pokazać i ujawnić wszystkie szwy tych hybryd. Przekraczając barierę tematów akceptowanych w Izraelu, ukazując skutki przemocowego przekraczania granic państwowych, granic człowieczeństwa, odpowiedzialności i nacjonalizmu, reżyser przekracza granice między prawdą a zmyśleniem. Celowo miesza fikcję i fakty, kreując ściśle autorski styl. Może to dezorientować odbiorców. Tak było w przypadku How I Learned to Overcome My Fear... który wiele osób uznało za klasyczny film dokumentalny i uwierzyło, że żona Mograbiego rzeczywiście go opuściła, a on sam naprawdę zaprzyjaźnił się z Arielem Sharonem ${ }^{23}$.

Mograbi rezygnuje z tradycyjnych gadających głów i przeplatania filmów archiwalnymi fotografiami z jeszcze innego powodu. Tworzy filmy polityczne z nadzieją na swego rodzaju sprawczość: Uważam, że każdy projekt, który zaczynam, zmieni rzeczywistość. Chce zmienić rzeczywistość ${ }^{24}$. Jego jedyną odpowiedzią na wewnętrzną potrzebę zmiany tego, co wokół, jest realizacja takiego filmu, który przyciągnie wielu widzów. Reżyser stwierdza: Mam wrażenie, że robiąc proste filmy dokumentalne, traci się widownię, ponieważ ludzie nie sa zainteresowani poważnymi dyskusjami politycznymi. W moich dwóch ostatnich filmach zaspokajam widzów, jak przy fabule; ogladaja więc film polityczny, nawet o tym nie wiedzac. Nie jestem pewien, czy obecnie mogę zrobić cokolwiek innego. Trzeba próbować zatrzymać swoja publiczność. Problemy w tym kraju sa tak głębokie, że jeśli zrobisz prosty film polityczny, stracisz widownię, ponieważ tutaj ludzie sa specjalistami od unikania wielkich problemów ${ }^{25}$. Dlatego też reżyser sięga po formy hybrydowe, które przez swą nieoczywistość mogą być dla widzów atrakcyjniejsze.

\section{Gonzo-dokument}

Ze względu na specyfikę strategii wykorzystywania dokumentalności i dającej się wyodrębnić metody twórczej nazwałabym filmy Mograbiego gonzo-dokumentami, gdyż przywodzą na myśl gonzo-journalism ${ }^{26}$. To subiektywny styl, w którym dziennikarz lub reporter nie jest obserwatorem, lecz osobiście angażuje się w prezentowaną historię, stając się jej częścią przez zastosowanie narracji pierwszoosobowej. Stopniowo wprowadza odbiorcę w świat swoich myśli i uczuć, oferując mu własną wersję prawdy ${ }^{27}$. Energiczny, partycypacyjny styl pisania, z autorem jako bohaterem spopularyzował w latach 70. Hunter S. Thompson. Siła oddziaływania jego tekstów najczéściej wynikała z połaczenia krytyki społecznej i autosatyry ${ }^{28}$. Z czasem styl ten zaczęto stosować $\mathrm{w}$ innych przedsięwzięciach artystycznych. Styl gonzo często zakłada wykorzystanie osobistego doświadczenia i emocji autora jako kontekstu dla poruszanych tematów, ale też pozwala wprowadzić do tekstu elementy fikcjonalne. Przy zamazywaniu granic między fikcją i faktem obowiązuje jednak swoista gonzo-etyka. Thompson wyraził to tak: Jeśli mam pójść w fantazję, to musze mieć mocne ugruntowanie w prawdzie. W przeciwnym razie wszystko, co piszę o polityce, może zostać odebrane jako halucynacja ${ }^{29}$. Styl gonzo posługuje się cytatami, sarkazmem, hiperbola, elipsa, aluzja, nagłym zwrotem, humorem, przesada i profanacja $q^{30}$, a także licznymi dygresjami, często (pozornie) niezwiązanymi z głównym wątkiem, a jednak ukazującymi temat w szerszej perspektywie interpretacyjnej. Ponieważ subiektywne opinie są tu traktowane jako środek wyrazu 
artystycznego, styl ten jest bliski zarówno dziennikarstwu, jak i beletrystyce ${ }^{31}$. Wywodzi się z nurtu Nowego Dziennikarstwa (lata 60. i 70. XX w.), u którego podstaw leżało przeświadczenie, że pisanie może być prawdziwsze i dosłowniejsze, gdy nie przestrzega się tradycyjnych prawideł tej sztuki. Elementami tekstów gonzo są często nie do końca zredagowane notatki, szkice i wywiady oraz dosłownie spisane rozmowy telefoniczne, telegramy; chodzi bowiem o uzyskanie efektu surowej spontaniczności i2. Większość elementów typowych dla gonzo-dziennikarstwa charakteryzuje także styl i metodę Mograbiego, który oprócz tego, że informuje o faktach i wykorzystuje materiały dokumentalne, to jednocześnie wyraża bardzo osobiste poglądy, a dodatkowo wprowadza element zabawy, co również skłania do refleksji nad naturą filmu dokumentalnego.

\section{Radykalne kino autorskie}

Mograbi porusza tematy niepopularne w Izraelu, m.in. indywidualnej odpowiedzialności obywateli, szkodliwości kultywowanych przez nich mitów czy winy żołnierzy w sensie sądowym. Zastanawia się też nad rolą pozycją i sprawczością filmowca w kraju, w którym codzienne akty przemocy są usankcjonowane politycznie i przez większość społeczeństwa uznawane za konieczność. Trudne do usytuowania w obrębie jednego paradygmatu filmy Mograbiego funkcjonują głównie jako dokumenty i do tej normy stylistycznej on sam się odnosi, ale robi to na własnych zasadach. Filmy te bywają nazywane esejami, filmami non fiction, dokumentami pierwszoosobowymi, wariacjami na temat pamiętników, dokumentami performatywnymi, a niektóre dokufarsami. Ja nazwałabym je hybrydami faktualnymi ${ }^{33}$. Sam reżyser określa osobnymi nazwami nawet poszczególne tytuły, co świadczy o pewnej trudności z zakwalifikowaniem ich po prostu do kina dokumentalnego. Natomiast trudno się zgodzić z opinią że Mograbi tworzy mockdokumenty ${ }^{34}$, bo jego filmy nie stanowią gry z widzem $\mathrm{w}$ takim właśnie znaczeniu: dotyczą faktów, zaś fikcję reżyser wykorzystuje do ich wzmocnienia. Autorefleksja na temat samej formy filmowej ma tu najczęściej znaczenie drugorzędne. Jedynie czasem reżyser sięga po pewne elementy mockdokumentalne.

Styl gonzo to taczenie rzeczywistości i fantazji w sposób, który bawi twórce i wstrzasa publicznościqa ${ }^{35}$, ale jej nie oszukuje i służy przede wszystkim dyskursowi faktualnemu (przekazowi ideowemu, przekazaniu faktów), a dopiero w drugim rzędzie celowi artystycznemu czy autorefleksji na temat formy. Mograbiemu nie chodzi tylko o zabawę forma; jeśli pojawia się tu element gry, to po to, by wzbogacić przekaz płynący z treści. To reżyser, dla którego główną motywacją twórczą jest potrzeba opowiadania, skutecznego wyjaśnienia własnych racji, przekazania swojej opinii w formie przyciągającej uwagę. Kieruje się instynktem, do każdego tematu szukając nowej formuły - ta czasem pojawia się w trakcie zdjęć, czasem na etapie montażu. Nie zmienia to faktu, że w jego filmach wyraźnie widać powtarzalność pewnych elementów (włączanie fikcji, motywy muzyczne, specyficzna gra aktorska i kreacja persony-reżysera), która stanowi o rozpoznawalności autorskiego stylu. W tym kontekście można mówić nie tylko o formach typowych dla Mograbiego, ale o swoistej poetyce tych filmów, o reżyserskim podpisie. To właśnie instynkt, którym kieruje się reżyser, poszukując formy dla wyrażenia interesujących go treści, pozwolił wykreować ten autorski styl - to styl wybrał twórcę, nie odwrotnie. 


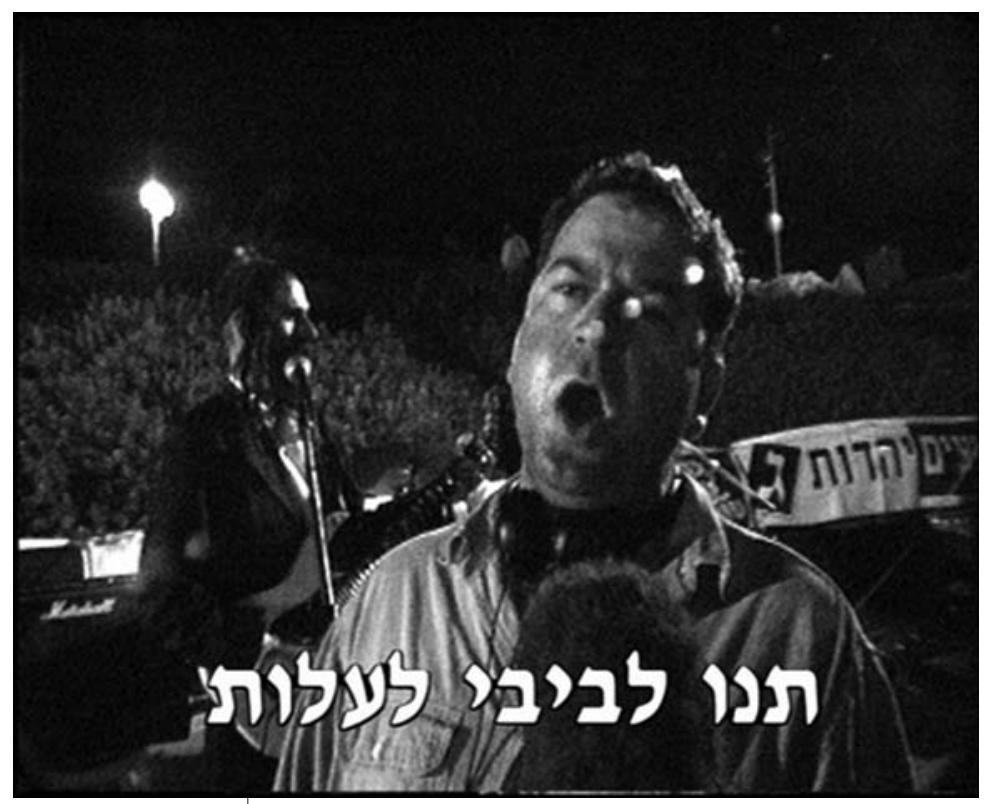

How I Learned to Overcome My Fear and Love Arik Sharon, reż. Avi Mograbi (1997)

Twórczość Mograbiego cechuje konsekwentny radykalizm treści i wysoce eksperymentalna forma (zwłaszcza w kontekście dokumentu i bardzo poważnej tematyki): stylizacja na pamiętnik (How I Learned to Overcome My Fear...), ironiczne komentarze (Happy Birthday, Mr. Mograbi, 1999), wplatanie humorystycznych scenek, w których sam reżyser odgrywa role kilku osób (August: A Moment Before the Eruption, 2002), włączanie form teatralnych (Between Fences, 2016), stworzenie sarkastycznego „podręcznika” okupacji (The First 54 Years - An Abbreviated Manual for Military Occupation, 2021) czy stylizacja filmowej spowiedzi bohatera na Opere za trzy grosze Bertolta Brechta $(Z 32,2008)$ z typowym efektem alienacji, kiedy komentator wprowadza poszczególne sceny, a w kluczowych momentach opowieści całkowicie z niej wychodzi i komentuje ja piosenkami w stylu kabaretowych songów Kurta Weilla, co może być odebrane jako niewłaściwa ironia lub bolesny absurd ${ }^{36}$. Eksperymenty Mograbiego, zarówno na obszarze rozwiązań narracyjnych, jak i warsztatowo-stylistycznych wywołują niekiedy szok u widzów i bywają przyczyną niezrozumienia czy odrzucenia jego filmów, z których każdy stanowi pewną odmianę realizatorskiej strategii reżysera, co zaprezentuję poniżej na wybranych przykładach.

\section{How I Learned to Overcome My Fear and Love Arik Sharon}

Christophe Postic i Pascale Paulat nazwali ten film wywrotowa i zaskakujaca burleska, która wstrzasa widzem i po każdym zwrocie zmienia jego perspektywę $e^{37}$. Mnie kojarzy się z dramma giocoso ${ }^{38}$, bo przeplata elementy poważne i komiczne. Film ma charakter pseudopamiętnika i jest mieszanką dokumentu (śledzącego kampanię wyborczą Ariela Sharona w 1996 r. z ramienia partii Likud) i fabularyzowanego 
wyznania (noszącego pewne cechy podrabianego dokumentu). Ukazuje rzekome polityczne uwiedzenie reżysera przez Sharona - ta zmiana światopoglądowa miała też być powodem odejścia jego żony. Mograbi, który nie należy do zwolenników Rzeźnika Libanu, nie ograniczył się do realizacji klasycznego dokumentu zestawiającego przykłady przewin polityka, lecz posłużył się forma, która pozwoliła mu go sportretować, wyrazić swoje poglądy i ukazać mechanizmy władzy. Zamiast szukać dramatycznego momentu, w którym ujawni się "prawda" o Sharonie, Mograbi udramatyzowat własna persone, wcielajac się w filmowca, który przechodzi transformacje i z lewicowego artysty staje się jego zwolennikiem ${ }^{39}$. W pierwszej scenie filmu reżyser, siedząc w swoim pokoju, mówi wprost do kamery (co stanie się jego zwyczajem), że Sharon, bohater jego dzieciństwa, rozczarował go i że ma do niego osobisty stosunek, bo za odmowę udziału w zainicjowanej przez polityka wojnie libańskiej w 1982 r. trafił do więzienia. Zachęcany przez żonę (której nigdy nie widzimy, ale jej opinia stanowi tu podstawę moralną) postanowił nakręcić film. Dalej następują zabawne sceny rzekomo ujawniające problemy przy realizacji filmu (m.in. liczne rozmowy telefoniczne, podczas których jest zbywany przez ludzi Sharona). Następnie oglądamy wyraźnie (choć pod względem etycznym niewinnie) zmanipulowane materiały dokumentalne z komentarzem Mograbiego z offu - opowiada swój sen o tym, jak zaczął lubić polityka i jego żonę. Ten lekki ton zostaje zakłócony pytaniem pani Sharon o powód uwięzienia reżysera i radiowymi doniesieniami z frontu libańskiego. Po czym znowu - wraz z kamerą Mograbiego - towarzyszymy rozbawionemu politykowi podczas rozmaitych spotkań. Ton narracji stale się zmienia: filmowiec ironizuje, czasem wręcz ośmiesza Sharona, po czym niby mimochodem wtrąca zdanie o wysadzeniu autobusu w Jerozolimie albo rzuca dwa słowa - Sabra i Szatila - przywołując wspomnienie masakry palestyńskich uchodźców w ych obozach w roku $1982^{40}$. Pokazuje też spotkania, podczas których Sharon jest atakowany za skutki swoich decyzji politycznych. Oczywiście rozdarcie „Mograbiego" między krytyką a sympatią jest jedynie pozorem - rzekoma zmiana zapatrywań politycznych Mograbiego to żart reżysera, wskazujący, jak łatwo miłe gesty polityka mogą wprowadzać w błąd co do jego prawdziwych intencji.

Wskazówka dotycząca interpretacji filmu jest zawarta już w jego tytule, nawiązującym do filmu Stanleya Kubricka Doktor Strangelove lub jak przestałem sie martwić i pokochałem bombe (Dr. Strangelove or How I Learned to Stop Worrying and Love the Bomb, 1964), będącego satyrą na zimnowojenny konflikt, a zwłaszcza na irracjonalność wojskowej doktryny wzajemnego unicestwienia. Natomiast forma filmu Mograbiego (który ugania się za Sharonem, by nakręcić o nim materiał) nawiązuje do filmu Michaela Moore'a Roger and Me (1989), w którym reżyser bez powodzenia próbuje przeprowadzić wywiad z Rogerem Smithem, byłym dyrektorem General Motors ${ }^{41}$. Żartobliwość sytuacji podkreśla rzekome rozstanie Mograbiego z żoną jako konsekwencja zmiany poglądów. W tym ironicznym, fikcjonalno-dokumentalnym filmie Mograbi opowiada historię powstawania filmu politycznego, który przerodził się w domowy melodramat przeplatany snami reżysera o Sharonie i o rozmowach z żoną polityka (sfilmowane rzeczywiste wypowiedzi obojga niekoniecznie były kierowane do Mograbiego). Ale prawdziwa historia opowiada o niemożliwym bliskim spotkaniu lewicy i prawicy we współczesnym Izraelu $^{42}$. To pozorne zbliżenie Mograbiego do Sharona jest tylko żartem, chociaż nie wszyscy ten żart zrozumieli ${ }^{43}$. 


\section{Happy Birthday, Mr. Mograbi}

Sam Mograbi określił ten film jako semi-documentary. Gra tu fikcyjnego filmowca Aviego Mograbiego, któremu zlecono nakręcenie dokumentu o obchodach 50. rocznicy Izraela i którego 42. urodziny przypadają w tym samym dniu co Dzień Niepodległości jego kraju ${ }^{44}$. Nie dość, że izraelski producent trzy razy zmienia zdanie co do charakteru filmu rocznicowego (najpierw chce, by było radośnie i zwycięsko, później - ostro jak na wojnie, a na koniec, by film niósł przesłanie pokoju), to jeszcze palestyński producent (fikcyjna postać grana przez palestyńskiego producenta Daouda Kuttaba) prosi o nakręcenie materiału z dawnych wiosek palestyńskich, zniszczonych przez kolonistów pół wieku wcześniej, bo data obchodzona przez izraelskich Żydów jako początek ich państwa dla Palestyńczyków jest Dniem Nakby (Yawm an-Nakba, co oznacza „Dzień Katastrofy”). Już sam ten zabieg można potraktować jako komentarz reżysera do złożonej sytuacji; w scenach mockdokumentalnych reżyser odsłania piętrzące się przed „Mograbim” trudności z realizacją filmu, a ostateczne niepowodzenie jego działań można uznać za metaforę beznadziei i nierozwiązywalności samego konfliktu. Przekaz ten wzmacnia fiasko prywatnego przedsięwzięcia „Mograbiego”. W pierwszej scenie persona reżysera (znowu ze swego pokoju) wprost do kamery opowiada o zakupie kawałka ziemi, który okazał się nieco większy, niż zostało to zarejestrowane w księgach, co doprowadziło do nieporozumień z właścicielami sąsiedniej działki. Ta historia opowiadana jak przypowieść, która do końca będzie się przeplatać z wątkiem realizacji filmu, jest wyrażoną metaforycznie aluzją polityczna, zastępującą jakikolwiek werbalny komentarz Mograbiego. Komentuje on wprost jedynie "swoje” życie prywatne, pozornie kwestionując własną rolę i zaangażowanie w przedstawioną rzeczywistość, dlatego interpretuje np. sprawy konfliktu, uciekając się do rozmaitych rozwiązań formalnych i sięgając po sardoniczny humor. Zestawiając pełne sztucznego patosu sceny obchodów izraelskiej rocznicy z przejmującymi obrazami zrujnowanych wiosek, precyzyjnie montując materiał fikcjonalny i dokumentalny, reżyser podkreśla nacjonalistyczny charakter jubileuszu i serwuje ostrą analizę kondycji narodu. Odzwierciedleniem poglądów reżysera na temat okupacji ziem palestyńskich jest zainscenizowana scena, w której małżeństwo z sąsiedniej działki wdziera się (widzimy tyko ich cienie) do domu „Mograbich” i demoluje go. Film jest majstersztykiem manipulacji filmowej w słusznej (bo dotyczącej praw człowieka) sprawie. Fikcjonalne są tu sekwencje z „Mograbim” mówiącym wprost do kamery, sceny z producentami, nabywcą domu; materiały dokumentalne to fragmenty pokazujące świętowanie rocznicy, wystąpienia polityków, telewizyjne relacje z zamieszek. Wątpliwości co do statusu mogą budzić sceny konfrontacji Mograbiego z ludźmi agresywnie reagującymi na jego kamerę. W filmie często pojawiają się sceny, które można odczytać jako pytania o rolę i powinności filmowca społecznie i politycznie zaangażowanego. Kiedy producent mówi, że pokój rozpada im się w rękach i tylko film Mograbiego może go ocalić, reżyser bezradnie odpowiada, że taki film jest niemożliwy. W tym kontekście sceny z przypadkowymi ludźmi wyraźnie zaniepokojonymi obecnością kamery nie tylko podkreślają atmosferę panującą w Izraelu, ale też mogą wskazywać rolę i miejsce filmowca w tamtejszym społeczeństwie, co sugerowałoby, że zostały przez reżysera zaplanowane i zainscenizowane. 

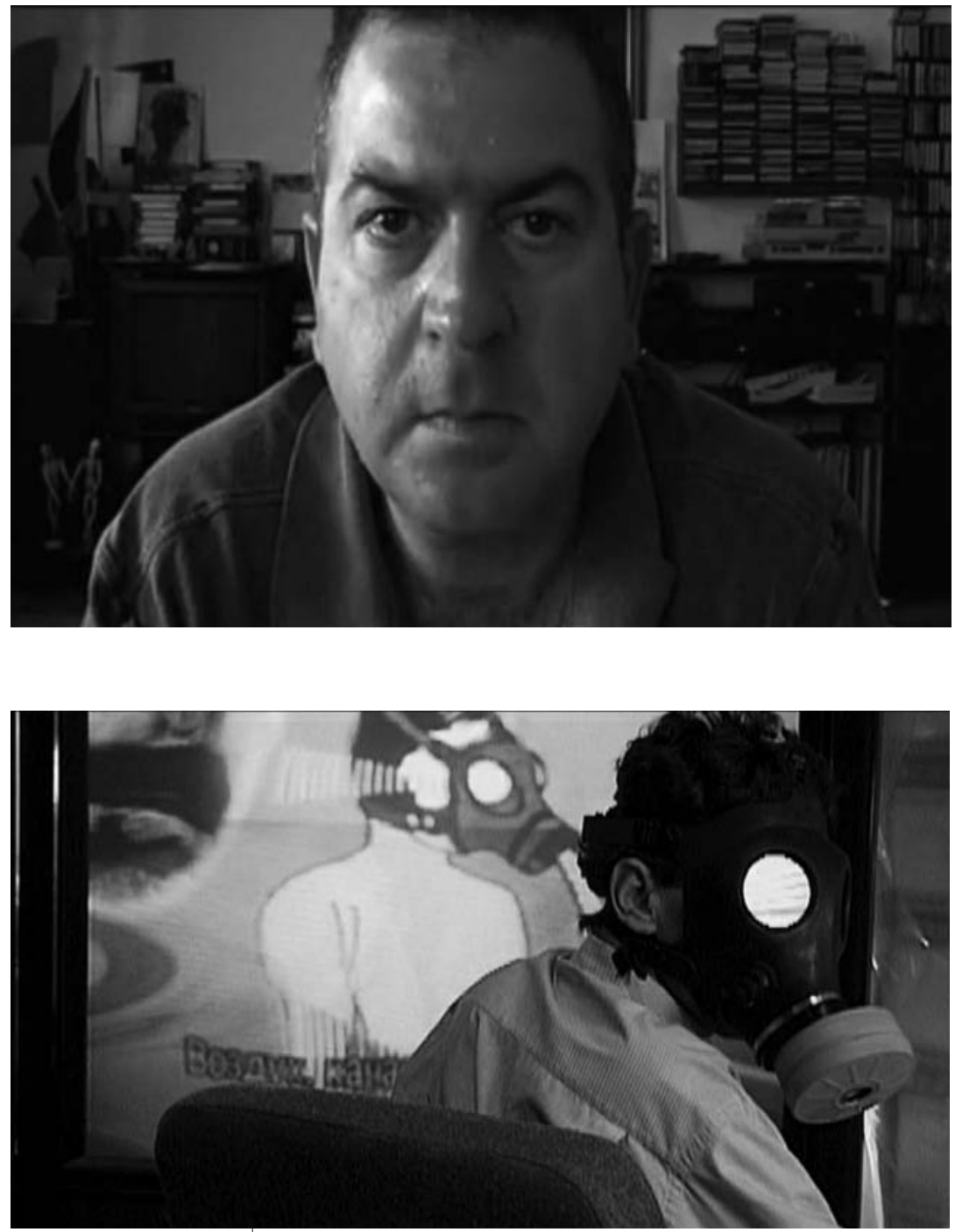

Happy Birthday, Mr. Mograbi, reż. Avi Mograbi (1999)

\section{August: A Moment Before the Eruption}

Pytania o rolę dokumentalisty, które w poprzednich filmach pojawiały się w tle kwestii polityczno-społecznych, tu wysuwają się na plan pierwszy. Mograbi zastanawia się, czy zadaniem zaangażowanego filmowca jest nieść pocieszenie, czy przeciwnie - ma czujnie odnotowywać tragiczne wydarzenia, czy też może ma być barometrem i dokumentalistą nastrojów. Wprawdzie formuła tego filmu jest 

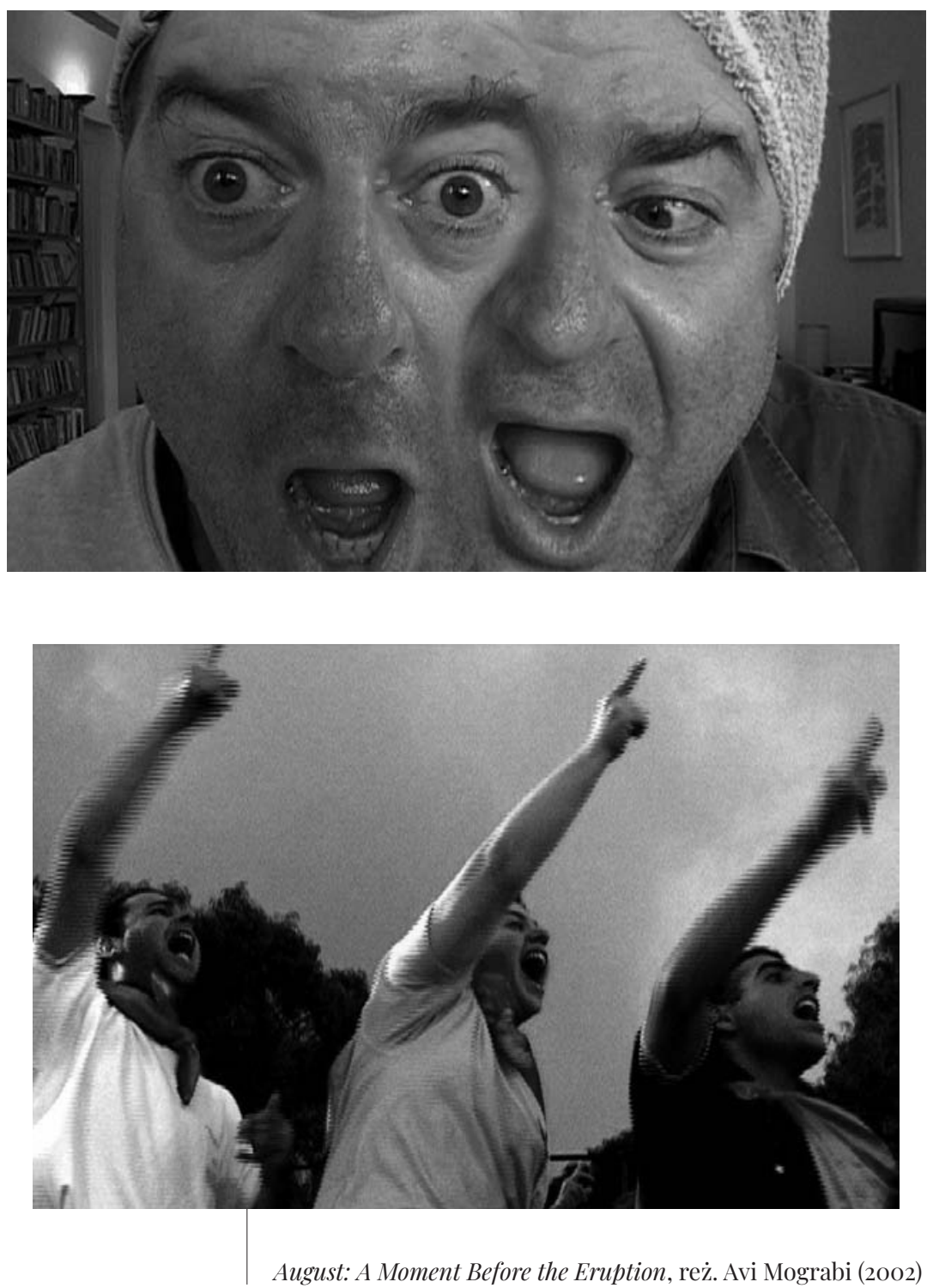

podobna jak w poprzednich (powaga i tragizm przeplatają się z szaleństwem i błazenadą), lecz pewne chwyty formalne zostały tu w oryginalny sposób zmodyfikowane: Mograbi wykorzystuje - jak dotychczas - swoją personę jako reżysera, ale też wciela się w dwie inne postaci, dzięki czemu aż trzy różne głosy mogą wyrażać jego rozterki. Tym razem film zaczyna się od migawki z wystąpienia Benjamina Netanjahu. Po tym materiale, tradycyjnie ze swego pokoju, "Mograbi” opowiada wprost do kamery, że zwierzył się żonie z zamiaru zrobienia filmu o najgorszym miesiącu roku - sierpniu. Nie wie jednak, o czym faktycznie film ma opowiadać. August... jest montażem fikcjonalnych „scen z pokoju”, materiałów 
dokumentalnych z oficjalnych wydarzeń (wśród nich są zapewne także zdjęcia udające dokumentalne) oraz zainscenizowanych przesłuchań aktorek do roli wdowy po Baruchu Goldsteinie, izraelskim lekarzu, osadniku z Zachodniego Brzegu, który w 1994 r. zmasakrował 29 Palestyńczyków modlących się w jaskini Machpela w Hebronie. Do nakręcenia o nim filmu próbuje „Mograbiego” nakłonić producent Ronny (w tej roli „Mograbi” w odwróconej czapce z daszkiem), natomiast żona („Mograbi” w różowym ręczniku na głowie) próbuje go przekonać do realizacji filmu, który poprawiłby widzom nastrój. W poprzednich realizacjach żona była obecna jedynie w relacjach reżysera - teraz pokazał ja, tyle że w sposób przewrotny. Wcielając w nią "Mograbiego", reżyser w pewnym sensie unieważnił związane z nią motywy (np. jej odejście). August... ujawnia zresztą więcej elementów procesu tworzenia niż poprzednie realizacje, co nie tylko odpowiada uczciwości w rozumieniu Mograbiego, ale wraz z zastosowanymi tu przerysowaniami stanowi swoisty autokomentarz do wcześniejszych filmów. Być może ma to związek z zamieszaniem, jakie wywołał film Happy Birthday, Mr. Mograbi, bowiem wiele osób odczytało go zbyt dosłownie. Dlatego też tym razem reżyser nie poprzestał na stawianiu pytań, lecz wyraźnie określił swoje stanowisko wobec roli dokumentalisty w Izraelu, choć nie wprost, ale za pośrednictwem wykreowanych przez siebie postaci. „Żona”, przeglądając doniesienia prasowe o zalewającej Izrael agresji, dochodzi do wniosku, że film powinien opowiadać o kondycji społeczeństwa. Opinia ta pokrywa się z doświadczeniem „Mograbiego” (Mograbiego?). Latem 2000 r. reżyser wyszedł z kamerą na ulice, chcąc zbadać nastroje społeczno-polityczne w Izraelu. Nie musiał nawet zadawać pytań, aby udokumentować panujący klimat - natychmiast bowiem spotkał się ze złością i zgorzknieniem stopniowo im uległając. Obecność jego kamery często wywoływała agresję, ale też ośmielała filmowanych do wyartykułowania swojej pogardy i nienawiści wobec innych. Dla osiągnięcia ekstremalnego efektu reżyser posłużył się też prowokacją, nawiązując do wspomnianej tradycji cinéma-vérité Roucha. Wywołał kryzys, by przetestować nastroje i pokazać, że sprowokowana sytuacja może się kiedyś naprawdę wydarzyć. Zatrudnił (czego nie kryje) grupę młodzieży przebranej w stroje arabskie, która na ulicach wykrzykiwała hasła głoszące, że izraelska ziemia to ich dom. Przechodnie byli tak zszokowani, że bez wahania dawali przed kamerą wyraz swemu oburzeniu. Reżyser rzucił też światło na kulisy powstawania dokumentów, chociażby w scenach przesłuchań aktorek ujawnił, jak można osiągnąć wiarygodny efekt zeznań świadków. We wspólnych sekwencjach „Mograbiego”, ,żony” i „producenta Ronny'ego” umyślnie niedbale i po amatorsku zastosował technikę split screen. Podzielony ekran wykorzystał także pod koniec filmu, aby swoiście skomentować dokumenty operujące sensacją i żerujące na tragicznych wydarzeniach. Można przypuszczać, że reżyser chciał w ten sposób zasugerować skojarzenia z pornografią: kiedy "Ronny” w pewnym momencie przesłuchuje do roli panią Goldstein „żonę” reżysera, ta zaczyna odgrywać płacz. „Producent”, tuż obok niej (split screen), gra to samo. Ich płacz przechodzi w ekstazę przypominającą orgazm. Ponieważ Mograbi wciela się tu we wszystkie zaangażowane strony, przypomina to - jak zauważył Shai Ginsburg akt miłości, który zamienia się w samogwałt ${ }^{45}$. 


\section{Avenge But One of My Tro Eyes}

W filmie tym, zrealizowanym w 2005 r., reżyser odchodzi od żartobliwego tonu, chociaż nie rezygnuje z charakterystycznego montażu scen fikcjonalnych i dokumentalnych. Mograbi jak zwykle pokazuje siebie przed i za kamera, ale tym razem w taki sposób, że jesteśmy skłonni uwierzyć, iż nie jest to już jedynie wykreowana persona. Film nakręcony podczas drugiej intifady ${ }^{46}$ pokazuje bolesna, nieludzką rzeczywistość, z którą każdego dnia styka się ludność palestyńska, nieustannie poniżana przez izraelską armię. Bada także sposób, w jaki armia odczłowiecza swoich żołnierzy, a co za tym idzie, całe społeczeństwo izraelskie (ze względu na powszechną służbę wojskową). Mograbi naprzemiennie prezentuje materiały reporterskie $\mathrm{z}$ fortyfikacji Zachodniego Brzegu i pustynnej fortecy Masada oraz obrazy grup (głównie) młodzieży przy znajdującym się tam pomniku. Reżyser mierzy się tu z dwoma kultywowanymi przez Izraelczyków mitami o byciu ofiarą: buntem przeciwko Rzymianom na górze Masada, gdzie 960 Żydów wolało wybrać zbiorowe samobójstwo, niż się poddać, oraz ostateczne poświęcenie się biblijnego bohatera Samsona, który w samobójczym akcie zburzył świątynię pełną Filistynów. Jego ostatnie wezwanie do Boga dało tytuł filmowi (a także rasistowskiej piosence rockowej śpiewanej w filmie przez zbuntowanych żydowskich suprematystów). Reżyser, zestawiając wychwalające te akty komentarze przewodników z wypowiedziami potępiającymi fanatyzm współczesnych palestyńskich zamachowców samobójców, wyraźnie wskazuje podobieństwo owych "heroicznych” czynów z obecnymi ich działaniami. Mograbi, który z jednej strony nie wierzy w dokumentalny obiektywizm, a z drugiej nigdy nie ucieka się do klasycznego komentarza, tym razem zastosował pomysłowy zabieg, by bezpośrednio wyrazić swoje poglądy. Otóż lejtmotywem filmu jest (zainscenizowana) rozmowa telefoniczna między „Mograbim” a jego palestyńskim „przyjacielem” ze strefy okupowanej (głos należy do aktora). W ten sposób zestawia perspektywę izraelską i palestyńska, obnażając ideologiczne fikcje. Dzięki rozmowie z przyjacielem zarejestrowanej jeszcze przed realizacją filmu Mograbi może wyrazić swoje opinie, które wygłasza „Mograbi”, a także ów „przyjaciel”. Konwersacja ta kreuje prowokacyjny portret kultury, której jedynym punktem odniesienia jest burzliwa - i niebezpiecznie wyabstrahowana przeszłośćc ${ }^{47}$. Widać to $\mathrm{w}$ tych scenach, gdy przewodnicy każą młodzieży wczuwać się w sytuację przodków, którzy popełnili samobójstwo, i we fragmentach ukazujących zindoktrynowane dzieci w szkole wygłaszające pochwałę kontrolowanej śmierci (lepiej zabić rodzinę i siebie, niż być niewolnikiem). Dzięki tym zabiegom film mówi więcej, niż mogłyby wyrazić głosy z oblężonego miasta. Każdy wydaje się interpretować zmitologizowaną historię jako część nieustannego cyklu prześladowań, sprawiedliwej walki i ciągłego zagrożenia ze strony otaczających go „Filistynów”. Pomysł na film zrodził się, gdy na początku 2002 r. po fali zamachów samobójczych w Izraelu rozgorzała dyskusja na temat „kultury śmierci" w islamie. Mograbi postanowił wtedy zrobić historyczny film dokumentalny o micie Masady i Samsona, które jego zdaniem wpisują się w „kulturę śmierci" w Izraelu. Zdecydował jednak, że zamiast wykorzystywać mapy, wykopaliska i rekonstrukcję, odwoła się do współczesnych scen z terytoriów okupowanych. Reżysera zainteresowało odwrócenie ról w Masadzie: Rzymianie to 
Izraelczycy, a Palestyńczycy to Żydzi. Samson zaś został potraktowany jako $\mathrm{w}$ pewnym sensie pierwszy $\mathrm{w}$ historii zamachowiec samobójca. $\mathrm{W}$ jednym z wywiadów Mograbi powiedział, że ludzie nie zdają sobie sprawy, do jakiego stopnia identyfikację z Samsonem wykorzystuje się do indoktrynacji młodzieży izraelskiej, która później, gdy wstępuje do armii, wykonuje brudną pracę i w żaden sposób jej nie kwestionuje. A mit o Masadzie jako ostatnim bastionie tych, którzy chcą być wolni, ma na celu zwiększenie gotowości Izraelczyków do walki. Przypisanie zaś islamowi „kultury śmierci” jest sposobem na wyciszenie dyskusji o tym, że to przez politykę Izraela Palestyńczycy nie widzą już większej różnicy między życiem a śmiercią. Jak mówi reżyser, Izrael cały czas żyje w świecie podwójnych standardów. Kiedy uczymy nasze dzieci o Samsonie jako bohaterze, nie widzimy, że to, co zrobit, bytoby dziś uznane za zbrodnię przeciwko ludzkości. Na terytoriach okupowanych wmawiamy sobie, że pracujemy nad stworzeniem "bezpieczeństwa”, i nie widzimy implikacji moralnych. Musimy przewartościować nasza kulturę i nasze czyny ${ }^{48}$.
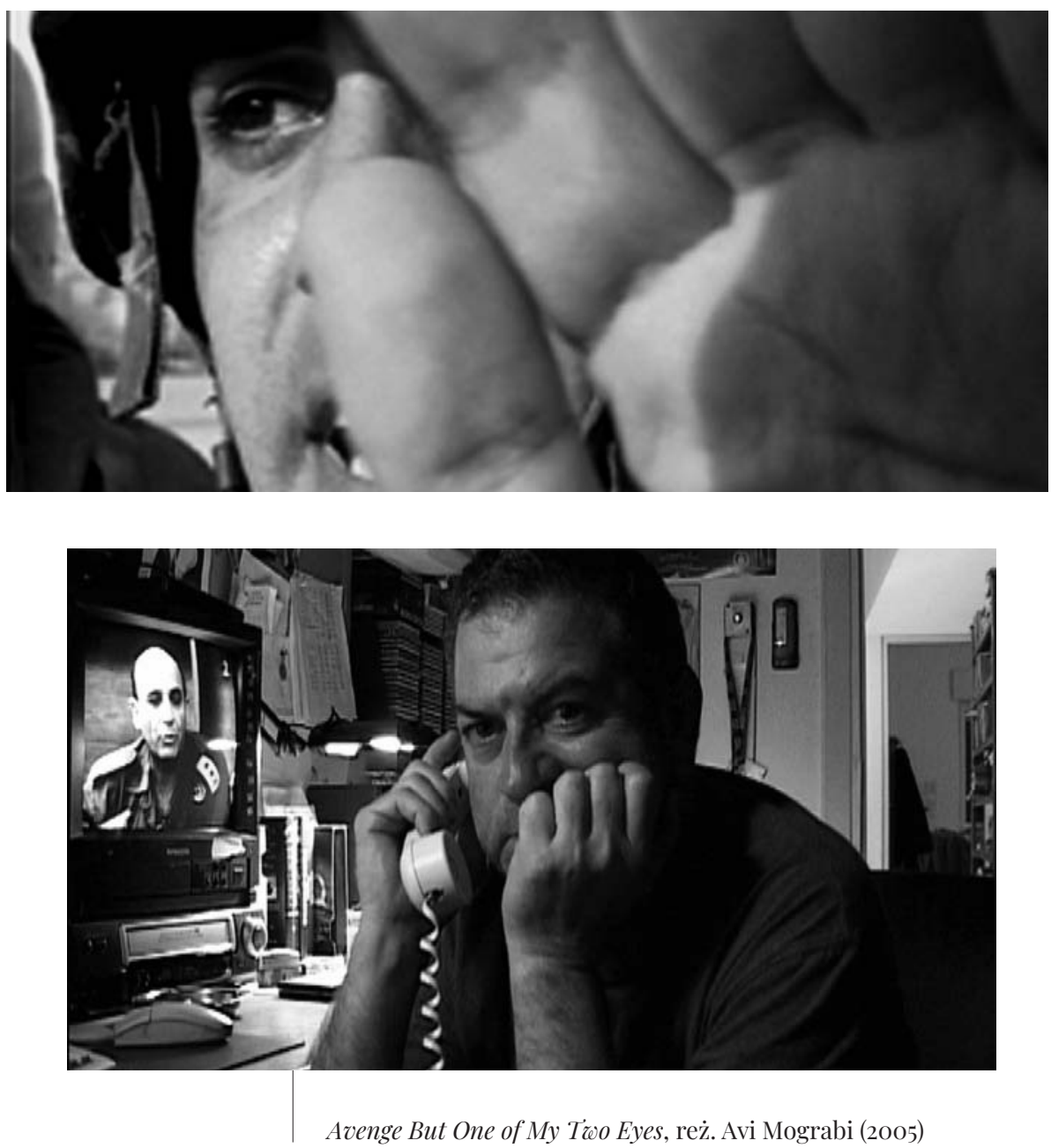


\section{$z 32$}

Reżyser zastosował tu bardzo radykalne rozwiązanie formalne. Film - ustrukturyzowany jak utwór Brechta z muzyką i piosenkami - rozwija wątki z poprzednich produkcji: opowiadając o młodym byłym żołnierzu z elitarnej jednostki wojskowej, badając w ten sposób poczucie winy u Izraelczyków. Tytuł odnosi się do pliku w archiwum Breaking the Silence, w którym Mograbi odkrył tę historię. Reżyser zestawia tu m.in. materiały $\mathrm{z}$ terenu, gdzie chłopak odbywał służbę, wywiad z nim, nagraną przez niego spowiedź/rozmowę z dziewczyną i „podpis Mograbiego", czyli wypowiedzi (a częściej - śpiew) wprost do kamery. Film zaczyna się od obrazu dwojga młodych ludzi rozmawiających przed kamerą wideo (na ich twarze nałożone są animowane w 3D maski, które uniemożliwiają identyfikację postaci). Następnie widzimy Mograbiego z pończochą na głowie, który siedząc w swoim pokoju, mówi do kamery, jak wyobraża sobie ten film, i sukcesywnie wycina w pończosze otwory na oczy, usta i nos, po czym zdejmuje „maskę". Początkowo planował, że zamaskowana postać dająca świadectwo wydarzeniom okaże się samym reżyserem, ale ostatecznie z tego zrezygnował. Następuje przeskok do wywiadu z byłym żołnierzem, którym jest chłopak z pierwszych scen filmu. Opowiada on o szkoleniu, które zamieniło go w impulsywną maszynę do zabijania, a następnie o jednej z akcji, w której jego jednostka miała pomścić morderstwo izraelskich żołnierzy. Ofiarami tej operacji stali się przypadkowi policjanci palestyńscy. Relacja ta jest przerywana rozmową z dziewczyną i scenami, w których Mograbi przygotowuje piosenki w stylu Kurta Weilla, stanowiące ironiczny komentarz do opowieści byłego żołnierza. Zabieg dystansuje nie tylko Mograbiego, ale także widzów - zarówno wobec wspomnień chłopaka, jak i jego rozmowy z partnerką. Film został zrealizowany w taki sposób, że jego dokumentalny status jest niejasny: nie wiemy, czy bohaterowie nie są aktorami ${ }^{49}$ (przypominają się tu aktorki ćwiczące rolę świadków w filmie August...). Ostatecznie nie ma to jednak znaczenia, bo sama historia, zaczerpnięta z archiwum, jest prawdziwa. Uświadamia to jednak ogromną różnicę między osobistym świadectwem a jego artystyczną reprezentacją rozłam między dręczącym doświadczeniem morderstwa a jego przeniesieniem na tekst filmowy, niemożliwą do pokonania przepaść między brutalnością rzeczywistości a dziełem sztuki jako narzędziem swoistego nawrócenia ${ }^{50}$. Mograbi określa swój film jako tragiczny musical dokumentalny. Opowieść izraelskiego żołnierza szukającego przebaczenia za zamordowanie palestyńskich funkcjonariuszy przerywają sceny, w których Mograbi z towarzyszeniem muzyków wyśpiewuje swój komentarz niczym chór grecki ${ }^{51}$. Zabieg ten podkreśla problematyczną ambiwalencję wobec tematu i być może ujawnia obawy twórcy przed konsekwencjami takiej historii dla niego samego i dla realizacji filmów w ogóle ${ }^{52}$. Mograbi rozmawiał z dwudziestokilkuletnim żołnierzem przez dwa lata i ostatecznie dał mu kamerę, żeby ten mógł sam sfilmować swoje konfesje. Dzięki temu prostemu zabiegowi reżyser - który jest pełnym empatii humanistą i antymilitarystą - mógł pozornie zatuszować swoje etyczne zaangażowanie w przedstawianą rzeczywistość, ukryć przed widzami własny dyskomfort wynikający ze współczucia pomieszanego z oskarżeniem. Takich sprzecznych emocji powinni doświadczać widzowie (zwłaszcza izraelscy), a nie tylko postaci na ekranie. Mograbi, badając poczucie winy 
Izraelczyków, ukazuje nieuświadamiane przez wielu jego rodaków tło przemocy systemowej i jej przejawy jednostkowe, pyta o osobiste i zbiorowe konsekwencje. Przedstawiony bohater jest sympatycznym, zwykłym chłopakiem, ale jest też mordercą. Jego dziewczyna nie potrafi prosto odpowiedzieć na pytanie, czy uważa go za zabójcę, i dać mu rozgrzeszenia. To bolesna kwestia moralna stojąca przed Izraelem, państwem nakazującym swoim żołnierzom bronić własnej ziemi i nadzorować terytorium, które prawnie do państwa tego nie należy. Reżyser po raz kolejny odwołuje się do rzekomej opinii żony (która na początku filmu przypadkiem na chwilę pojawiła się w kadrze), co pozwoliło mu łatwiej (i atrakcyjniej) wyrazić własne rozterki i dylematy.

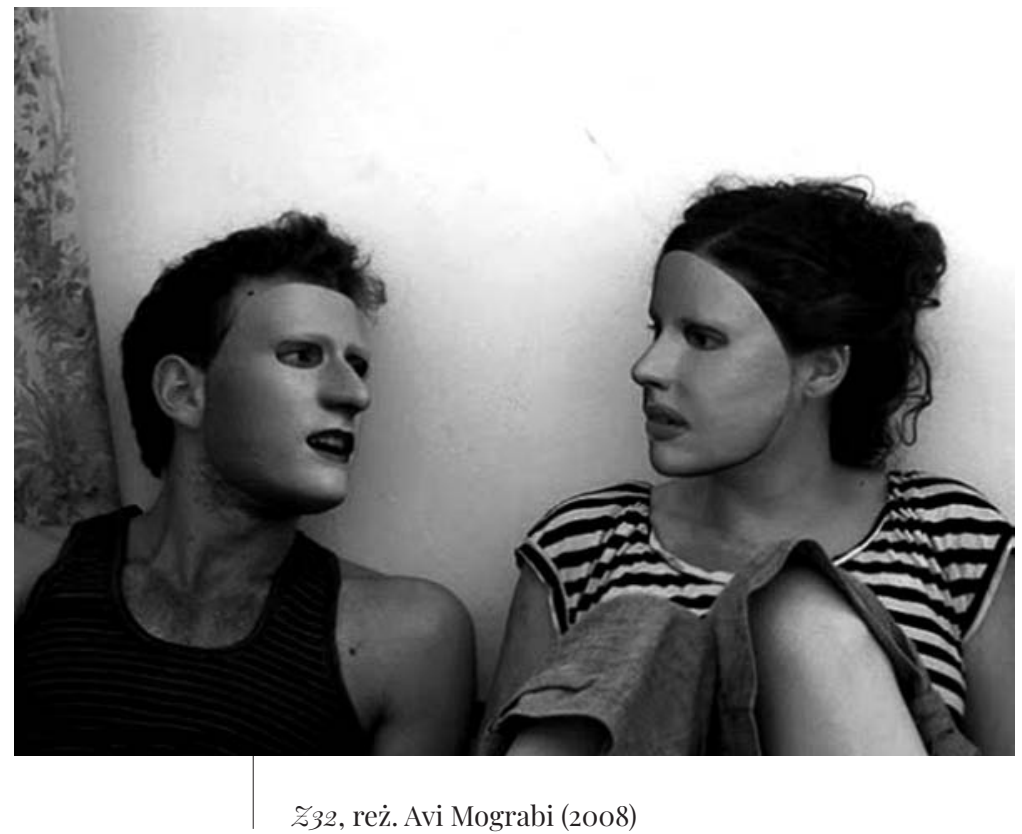

\section{Between Fences}

Do dokumentu o afrykańskich uchodźcach Mograbi włączył tym razem teatr. Od 2007 r. do momentu realizacji filmu przedostało się do Izraela przez granicę z Egiptem ok. 50 tys. Erytrejczyków i Sudańczyków. Polityka państwa wobec nich polega na nałożeniu tymczasowego zakazu deportacji. Osoby bez statusu azylantów i dokumentów potwierdzających ich tożsamość, pozbawione podstawowych praw i dostępu do usług socjalnych, były przetrzymywane, czasem przez kilka lat, w Holot - odizolowanym ośrodku na pustyni Negew. Mograbi i Chen Alon przeprowadzili tam warsztaty teatralne z ludźmi, którzy znaleźli się w najbardziej niepewnej sytuacji. Używając technik Teatru Uciśnionych brazylijskiego dramaturga Augusta Boala, twórcy próbowali zilustrować bezradność uchodźców i sproblematyzować ich dyskryminację w kraju, który przecież sam został założony przez uchodźców. Tym razem Mograbi zrezygnował z żartobliwego tonu i typowych dla niego sekwencji fikcjonalnych, by zastąpić je scenkami teatralnymi. Azylanci opowiadają swoje historie 

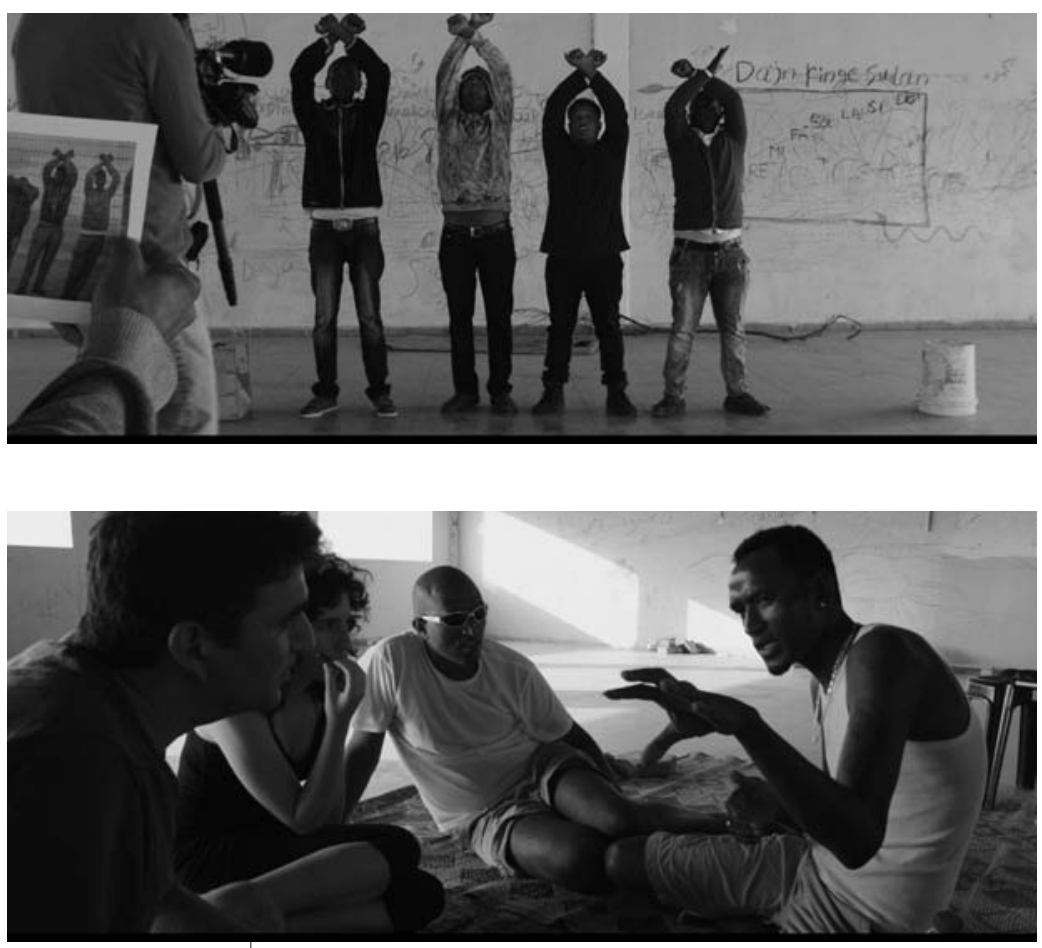

Betæeen Fences, reż. Avi Mograbi (2016)

przed kamera, a następnie odgrywają je podczas warsztatów. W filmie znalazł się także materiał zarejestrowany w czerwcu 2014 r., kiedy to 700 azylantów opuściło ośrodek na znak protestu, domagając się przynależnych im praw albo pozwolenia na opuszczenie Izraela. Ponieważ złamali prawo (!), zostali zatrzymani przez izraelskie wojsko i osadzeni w więzieniu Saharonin, a po trzech miesiącach z powrotem odesłani do Holot. Dokumentując warsztaty teatralne, Mograbi chciał doprowadzić do zmian politycznych i legislacyjnych, które odmieniłyby los tych ludzi, oraz zmusić społeczeństwo izraelskie do uznania sytuacji uchodźców za jeden z rozdziałów własnej historii. Sevara Pan zauważyła, że warsztaty i ich rejestracja stworzyły zatrzymanym przestrzeń przynależności, którą wcześniej utracili. Przypomniała też, że ów brak przynależności opisał niegdyś palestyński poeta Mahmoud Darwish jako rzeczywistość pomiędzy ogrodzeniami, jako że nie można do niej wejść i nie można z niej wyjść. W Holot azylanci wcielili się - jej zdaniem - w role "obecnych-nieobecnych", którzy sa poza domem, ale jeszcze nie w Izraelu ${ }^{53}$. Mograbi zachęcał Afrykańczyków do uobecnienia się w tej nieobecności. Azylanci mogli więc nie tylko odgrywać własne historie, ale mieli też możliwość reżyserowania niektórych scen, jakby odzyskując swe opowieści. Odzwierciedleniem dążenia do wyeksponowania ich obecności jest - nietypowa dla Mograbiego - rezygnacja z lokowania w filmie swojej persony i z natarczywego epatowania wizerunkiem: cały czas słyszymy jego głos, patrzymy na rzeczywistość okiem jego kamery, ale widzimy go tylko czasem, gdy filmuje warsztaty. Symbolicznym przywróceniem tożsamości uczestnikom zajęć jest także wymienienie każdego z imienia i nazwiska w napisach końcowych. 


\section{The First 54 Years: An Abbreviated Manual for Military Occupation}

Jest to z jednej strony film o izraelskiej okupacji terytoriów palestyńskich w Strefie Gazy, a z drugiej uniwersalna opowieść o formie kontroli w ogóle. Avi Mograbi przedstawia widzom - ponownie ze swojego fotela w salonie - wojskowy podręcznik okupacji. Jego refleksje dotyczące strategii mają wymowę pozornie niewinnych, ogólnych rozważań na temat tego, w jaki sposób można z powodzeniem zająć obce terytorium wbrew wszelkiemu oporowi, ale głównym przykładem jest tu oczywiście izraelska okupacja terytoriów palestyńskich. Pełna gorzkiej ironii i sarkazmu instrukcja jest zestawiona z relacjami 38 izraelskich żołnierzy zebranymi dla organizacji Breaking the Silence. Relacje te dają wgląd w historyczne etapy okupowania tych ziem i powszednią rutynę egzekwowania kontroli. Do tych pozbawionych emocji opisów codziennych okrucieństw zostały dołączone materiały przedstawiające zbrodnie wojskowe. Połączenie trzech rodzajów narracji jest bardzo sugestywne i zmusza do konfrontacji z psychologicznymi skutkami konfliktu w obu społeczeństwach; reżyser, choć opowiada się po stronie uciśnionych, dostrzega i opisuje spustoszenia po każdej ze stron. W jednym z wywiadów podczas Berlinale 2021 zaznaczył zreszta, że film ten nie miał na celu nikogo zadowolićs4. Mograbi, wykorzystując relacje wojskowych, ujawnia po prostu mechanizmy maszyny okupacyjnej. Jak zwraca uwagę Ela Bittencourt, obrazy nalotów wraz z zeznaniami żołnierzy, którzy je przeprowadzali, odzyskują swój status prawdziwości, a sam Mograbi przywraca kontekstualność, o której Susan Sontag pisała w książce Widok cudzego cierpienia, podkreślając, że w naszych technologicznych czasach, kiedy manipulacja jest powszechna, a indeksowy status obrazu kwestionowany, sam obraz już nie wystar$c z a^{55}$. Pomysł podręcznika zrodził się, kiedy Mograbi, przejrzawszy całe archiwum Breaking the Silence, zdał sobie sprawę, że zaprezentowanie samych świadectw może jedynie pokazać, jak wygląda i przebiega okupacja, natomiast ujęcie w ramy powiązań tych zeznań, wskazujących pewne metody i mechanizmy, odsłoni określone cele, którym one służyły. Uznał, że będzie tu potrzebny narrator-instruktor, w którego rolę sam się wcielił. Jego persona musiała być częścią sił okupacyjnych, nie mogła więc reprezentować opozycji. Stworzył zatem postać makiaweliczna, która nie podziela wyznawanych przez niego wartości. Dlatego też film ten jest znacznie bardziej gorzki niż poprzednie produkcje Mograbiego. Reżyser wyznał, że choć zawsze miał w zwyczaju reagować na sytuację polityczną z humorem, jej niezmienność sprawiła, że z czasem jego humor zaczął topnieć. Przez lata $\mathrm{w}$ jakimś stopniu wierzył w moc oddziaływania filmu na rzeczywistość i politykę. Teraz zrozumiał, że przekonanie o sprawczości filmu, jakie towarzyszyło mu przy każdej produkcji, było tylko energią twórcza, a niekoniecznie energią realnych zmian ${ }^{56}$. Fakty mówią w tym filmie same za siebie, wyznania żołnierzy dokładnie wyjaśniaja, na czym polega okupacja, ale i tu Mograbi wyraża swój chłodny gniew, tyle że nie w bezpośrednim komentarzu, ale niejako à rebours, w wyważonym sposobie prezentacji podręcznika i w doborze słów (gdy np. nazywa zawłaszczanie ziemi „wyższym celem”). Ela Bittencourt zauważyła, że przyjmując ten znużony, pseudopolityczny ton, Mograbi znowu stworzył dystansujaca, na wpót brechtowska ramę $e^{57}$. 

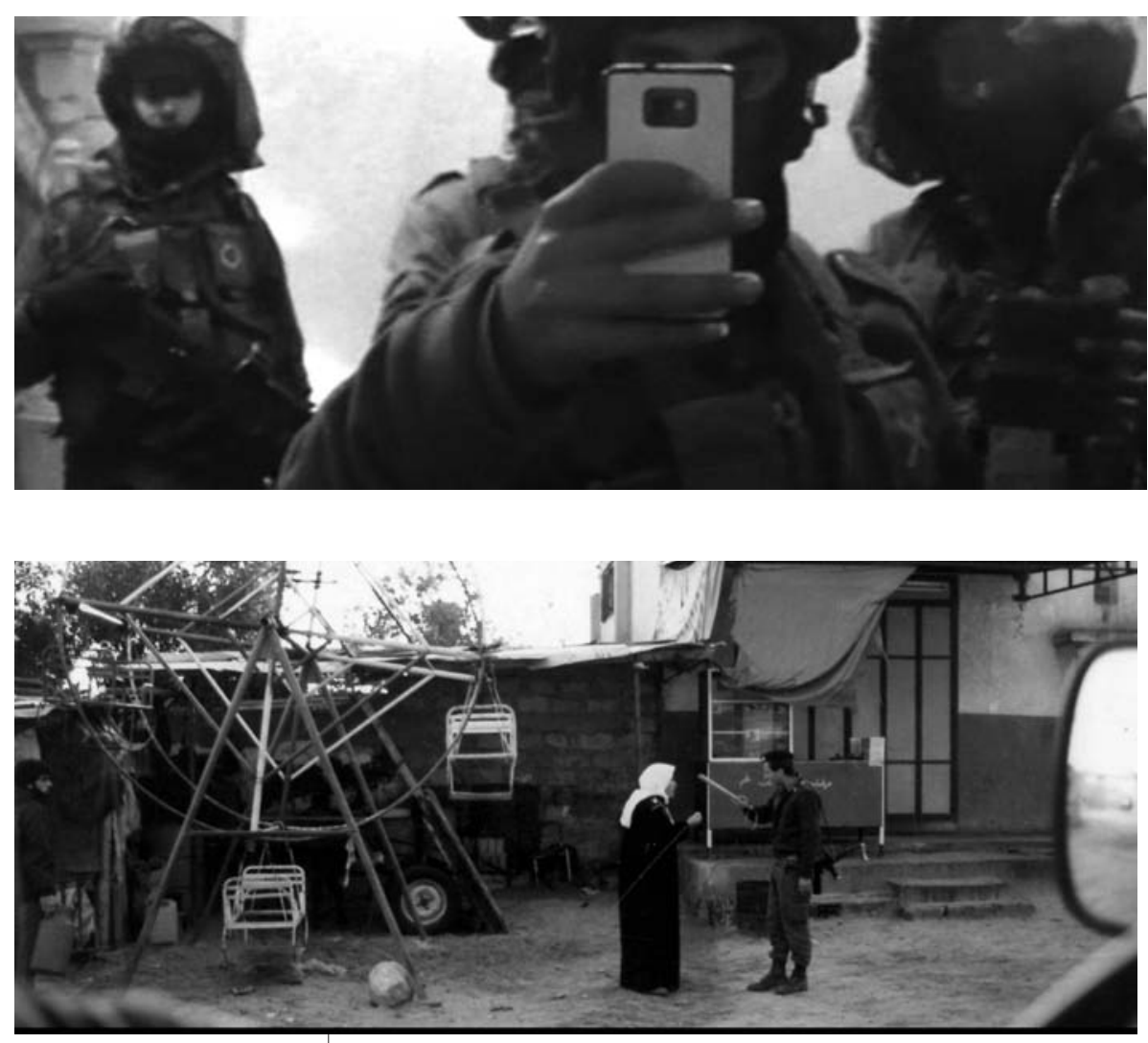

The First 54 Years: An Abbreviated Manual

for Military Occupation, reż. Avi Mograbi (2021)

\section{Podsumowanie}

Splatanie przez Mograbiego sekwencji dokumentalnych ze scenkami dramatycznymi i ekspresją własnych poglądów nie odpowiada oczywiście na pytanie, co znaczy dokumentować za pomocą kamery przy realizacji filmu politycznego. Inni twórcy, obierając ten sam cel, stosowali i stosują przecież skrajnie odmienne strategie. Jego strategia rzuca jedynie światło na naturę „rzeczywistości” w filmach dokumentalnych i na sposób, w jaki rzeczywistość determinuje tworzenie filmów i samego filmowca ${ }^{58}$. Brak zainteresowania dla prostych rozwiązań formalnych wynika z nieufności do modelu dokumentalizmu, w którym reżyser, udając obiektywizm, niejako ukrywa swój kreacyjny wkład. Reżyser dzięki personie „Aviego Mograbiego", wprowadzając do filmów własny wizerunek i ujawniając procesu jego powstawania, zaznacza nie tylko swoją fizyczność dla uatrakcyjnienia formy, ale przede wszystkim podkreśla swoją mentalną obecność, przez którą przefiltrowuje rzeczywistość. To ujawnienie się ma zasadnicze znaczenie dla kluczowej tu kwestii uczciwości filmowca. Dla Mograbiego ukazywanie rzeczywistości nie może się obyć 
bez fikcji, a najistotniejszym aspektem świata przedstawionego jest sam dokumentalista i jego rola w powstawaniu filmu, proces tworzenia. Reżyser wykorzystuje swoje "dokumenty", by zadawać trudne pytania, patrząc przy tym na pokazywane kwestie przez pryzmat "niesfornego dziecka" (...). Przez swój niepowtarzalny styl artystyczny stara się ukazać skomplikowana żydowska tożsamość: wyśmiewa samego siebie, nie przestając poważnie podchodzić do tematu, taczy polityke z perspektywa osobista ${ }^{59}$. Nowa, oryginalna stylistycznie forma zawsze prowokuje do refleksji i pytań, i o to chyba chodzi Mograbiemu. Ironia stała się dla niego najlepszym narzędziem pedagogicznym, ale nie w miejsce pełnej powagi wobec tematu, jak utrzymuje David Katz ${ }^{60}$, tylko obok. W twórczości Izraelczyka da się dostrzec pewne stałe motywy: przede wszystkim niemal instynktowny antymilitaryzm reżysera oraz głębokie współczucie nie tylko dla sprawy palestyńskiej, ale dla wszystkich tych, których prawa są łamane. Strategia twórcza, polegająca na zestawianiu elementów z różnych porządków, pozwala znakomicie wybrzmieć uniwersalnemu przekazowi o absurdalności wojen i wszelkich konfliktów, nie umniejszając przy tym tragizmu konkretnej, przedstawionej w danym filmie historii. Dzięki zastosowaniu stylu gonzo Mograbi rozśmiesza widzów, szokuje i prowokuje (zwłaszcza swoich rodaków), a także skłania do zweryfikowania własnych przyzwyczajeń myślowych (giez kłujący gnuśnego konia), podjęcia krytycznej refleksji na temat polityki kraju, zastanowienia, co tak naprawdę określa ich narodową tożsamość. Mograbi nie tylko wzmacnia przez formę ideologiczne przesłanie swoich filmów, ale też przekazuje wiedzę o konkretnych faktach. Michael Chanan napisał: Potrzeba nam znacznie więcej takich filmów, zanim będziemy naprawdę dobrze poinformowani o stanie świata, w którym żyjemy ${ }^{61}$.

${ }^{1}$ C. Raven, Know Nothing about Afghanistan? Blame the Death of the Documentary, "The Guardian", 30.10.2001, https://www.theguardian.com/world/2001/oct/30/afghanistan.comment (dostęp 25.09.2021).

${ }^{2}$ C. Svetvilas, Hybrid Reality: When Documentary and Fiction Breed to Create a Better Truth, „IDA Documentary Magazine", 30.06.2004, https://www.documentary.org/feature/hybrid-reality-when-documentary-and-fictionbreed-create-better-truth (dostęp: 25.09.2021).

${ }^{3}$ Cyt. za: tamże.

${ }^{4}$ Zob. M. Sicinski, Gadfly in the Holy Land: the Critical Cinema of Avi Mograbi, "Notebook", 17.03.2017, https://mubi.com/notebook/posts/gadfly-in-the-holy-land-the-critical-cinemaof-avi-mograbi (dostęp: 21.06.2021); J. Weissberg, "The First 54 Years - An Abbreviated Manual for Military Occupation" Review, "Variety”, 10.03.2021, https://variety.com/2021/film/reviews/the-first-54-years-an-abbreviated-manual-for-military-occupation-review1234924325/ (dostęp: 25.09.2021).

${ }^{5}$ Zob. Platona, Eutyfron, Obrona Sokratesa, Kriton, tłum. W. Witwicki, Książnica Polska T-wa
Naucz. Szkół Wyższych, Lwów - Warszawa 1920, s. 111.

${ }^{6}$ A Fly in the Soup - Avi Mograbi, https://dafilms.com/program/407-fly_in_the_soup_avi_mograbi_news (dostęp: 15.06.2021).

${ }^{7}$ Filmy te nie mogły być emitowane w izraelskiej telewizji.

${ }^{8} \mathrm{Z}$ tekstu do materiału filmowego: Crossings: Masterclass with Avi Mograbi, 19.08.2017, https://archive.ica.art/whats-on/crossings-masterclass-avi-mograbi (dostęp: 2.07.2021).

${ }^{9}$ https://www.pswar.org/index/participants/avimograbi/ (dostęp: 21.06.2021).

${ }^{10}$ R. Scheib, "August: A Moment Before the Eruption", "Variety", 9.07.2002, https://variety.com/2002/film/reviews/august-a-momentbefore-the-eruption-1200547408/ (dostęp: 25.09.2021).

${ }^{11}$ Szlemiel w jidysz oznacza m.in. nieudacznika, ofermę, pechowca. Mograbiego szlemielem nazwał też m.in. M. Sicinski, Gadfly in... dz. cyt.

12 Por. A Fly in the Soup... dz. cyt.

${ }^{13}$ Zwraca na to uwage m.in. M. Sicinski (Gadfly in... dz. cyt.) oraz M. Chanan (August, ,Vertigo", t. 2, nr 3, lato 2002, https://www.closeup- 
filmcentre.com/vertigo_magazine/volume-2issue-3-summer-2002/august/ /dostęp: 4.07.2021/).

14 Zob. Christophe Postic i Pascale Paulat, https://on-tenk.com/en/documentaires/fragments-dune-oeuvre/comment-j-ai-appris-asurmonter-ma-peur-et-a-aimer-ariel-sharon (dostęp: 21.06.2021).

15 Por. N. Dolara, Avi Mograbi, el documentalista sin fórmula, "The Objective”, 27.03.2017, https://theobjective.com/further/avi-mograbiel-documentalista-sin-formula (dostęp: 21.06.2021).

${ }^{16}$ Tamże.

17 Tamże.

${ }^{18}$ T. Steen Müller, Avi Mograbi: In Between Genres, „Modern Times Review”, 1.07.2001, https://www.moderntimes.review/in-betweengenres/ (dostęp: 20.09.2021).

${ }^{19}$ M. Miller, Voices within the Siege: An Interview with Avi Mograbi, „Cineaste Magazine” 2007, t. 32, nr 3, https://www.cineaste.com/summer2007/voices-within-the-siege-an-interviewwith-avi-mograbi (dostęp: 20.09.2021).

${ }^{20}$ https://www.zabludowiczcollection.com/collection/artists/view/avi-mograbi

${ }^{21}$ Cyt. za: C. Svetvilas, dz. cyt.

${ }^{22}$ Zob. T. Steen Müller, dz. cyt.

${ }^{23}$ Tamże.

${ }^{24}$ P. Aufderheide, Avi Mograbi: Activist and Filmmaker, Center for Media \& Social Impact, 28.10.2016, https://cmsimpact.org/documentary-independent-and-public-media/avi-mograbi/ (dostęp: 20.09.2021).

${ }^{25}$ T. Steen Müller, dz. cyt.

${ }^{26}$ Zob. J. Mosser, What's Gonzo about Gonzo Journalism?, „Literary Journalism Studies” 2012, t. $4, \mathrm{nr} 1$.

27 Zob. m.in. M. Gliński, Ziemowit Szczerek, https://culture.pl/pl/tworca/ziemowit-szczerek (dostęp: 14.08.2021).

${ }^{28}$ B. J. Bowe, A Brain Full of Contraband: The Islamic Gonzo Writing of Michael Muhammad Knight, „Literary Journalism Studies” 2012, t. 4, nr 1, S. 92.

${ }^{29}$ P. J. O'Rourke, Interview with Hunter S. Thompson, w: Ancient Gonzo Wisdom: Interviews with Hunter S. Thompson, red. A. Thompson, Da Capo Press, New York 2009, s. 153. (Tekst ten był wcześniej opublikowany w: „Rolling Sto-

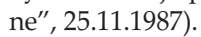

${ }^{30}$ N. J. John, P. Sharma, Gonzo Journalism - An Ethnography Study, "International Journal of Science and Research" 2020, t. 9, nr 8, s. 19. DOI: $10.21275 /$ SR20724100731

31 Gonzo - warsztat reportażu subiektywnego, https://www.gdansk.pl/wydarzenia/Gonzo- warsztat-reportazu-subiektywnego,w,16782 (dostęp: 21.06.2021).

${ }^{32}$ H. S. Thompson, Fear and Loathing in Las Vegas: A Savage Journey to the Heart of the American Dream, w: tegoz: The Great Shark Hunt: Strange Tales from a Strange Time, Summit Books, New York 1979, s. 106.

${ }^{33}$ Por. B. Kosińska-Krippner, Problemy genologiczne z pejzażem telewizyjnym. Propozycja klasyfikacji faktualnych gatunków hybrydowych i gatunków "reality TV”, „Kwartalnik Filmowy” 2020, nr 112, s. 38-64.

${ }^{34}$ A. S. Lebow, First Person Jewish, University of Minnesota Press, Minneapolis - London, 2008, s. XXI.

${ }^{35}$ J. Filiatreau, Who is Raoul Duke?, "Courier-Journal", 23.10.1975.

${ }^{36}$ A Fly in the Soup... dz. cyt.

${ }^{37}$ Ch. Postic, P. Paulat, dz. cyt.

${ }^{38}$ Połączenie stylistyk dwóch głównych gatunków operowych - opery seria i buffa.

39 Always the Trouble with Avi, https://www.adkdw.org/en/article/659_always_the_trouble_w ith_avi (dostęp: 2.07.2021).

${ }^{40}$ Najprawdopodobniej Sharon osobiście udzielił milicjom maronickiej Falangi pozwolenia na akcję w obozach uchodźców i był jedynym człowiekiem, który mógł jej zapobiec. Zob. R. Frister, Zapomniana zbrodnia. 35. rocznica masakry w obozach Sabra i Szatila, "Polityka”, 16.09.2017.

${ }^{41}$ Zob. M. Amon, "How I Learned to Overcome My Fear and Love Arik Sharon", "Review of Middle East Studies" 1999, t. 33, nr 1, s. 146.

${ }^{42} \mathrm{https}$ //dafilms.com/film/8064-how-i-learnedto-overcome-my-fear (dostęp: 21.06.2021).

${ }^{43}$ Niektórzy krytycy odczytali film dosłownie. Zob. M. Amon, dz. cyt.

${ }^{44}$ W 2012 r., odwołując się do tego filmu, Akram Zaatari wydał fikcyjną rozmowę z wyimaginowanym izraelskim filmowcem Avim Mograbim. Zob. A Conversation with an Imagined Israeli Filmmaker Named Avi Mograbi, https://mitpress.mit.edu/books/conversationimagined-israeli-filmmaker-named-avi-mograbi (dostęp: 21.06.2021).

${ }^{45}$ S. Ginsburg, Studying Violence: The Films of Avi Mograbi, https://takriv.net/english-article/studying-violence-the-films-of-avi-mograbi/ (dostęp: 21.06.2021).

${ }^{46}$ Intifada (arab. bunt, powstanie) Palestyńczyków przeciwko władzom izraelskim (20002005). Wielu Palestyńczyków uważa, że intifada jest narodowowyzwoleńczą walką z okupacją izraelską, jednak Izraelczycy postrzegają ją jako walkę terrorystyczną. Zob. m.in. B. Araj, R. J. Brym, Intifada, w: Encyclopaedia Britannica, 
https://www.britannica.com/topic/intifadah (dostęp: 12.08.2021).

${ }^{47} \mathrm{M}$. Miller, dz. cyt.

${ }^{48}$ Tamże.

49 Zob. D. Fainaru, "Z32”, „Screendaily”, 29.08.2008, https://www.screendaily.com/z32/4040413.article (dostęp: 12.08.2021).

${ }^{50}$ Zob. Always the Trouble with Avi, dz. cyt.

51 Tamże.

${ }^{52}$ Zob. S. Ginsburg, dz. cyt.

${ }^{53}$ S. Pan, Arab Docs at the Berlinale: Straddling between Fiction and Non-Fiction, "IDA Documentary Magazine", 7.03.2016, https://www.documentary.org/online-feature/arab-docs-berlinale-straddling-between-fiction-and-non-fiction (dostęp 17.07.2021).

${ }^{54} \mathrm{Z}$ rozmowy Cristiny Nord z reżyserem przeprowadzonej podczas Berlinalehttps://www.youtube.com/watch? $\mathrm{v}=\mathrm{MU} 85 \mathrm{rFePu} \mathrm{M}$ (dostęp: 4.07.2021).
${ }^{55}$ Cyt. za: E. Bittencourt, Berlinale Review: „The First 54 Years - An Abbreviated Manual for A Military Occupation", 17.03.2021, https://mubi.com/notebook/posts/berlinale-review-thefirst-54-years-an-abbreviated-manual-for-amilitary-occupation (dostęp: 13.09.2021).

${ }^{56}$ Ze wspomnianej rozmowy Cristiny Nord z reżyserem https://www.youtube.com/watch?v=MU85rFePu7M (dostęp: 4.07.2021).

${ }^{57}$ E. Bittencourt, dz. cyt.

${ }^{58}$ S. Ginsburg, dz. cyt.

${ }^{59}$ Avi Mograbi: Israeli Enfant Terrible, https://dafilms.com/program/667-avi-mograbi (4.07.2021).

${ }^{60}$ D. Katz, Review: "The First 54 Years: An Abbreviated Manual for Military Occupation", 9.03.2021, https://cineuropa.org/en/newsdetail/398603/ (dostęp: 4.07.2021).

${ }^{61}$ M. Chanan, dz. cyt.
Beata Kosińska-Krippner
Doktor nauk humanistycznych w zakresie filmoznawstwa i medioznawstwa; adiunkt w Instytucie Sztuki Polskiej Akademii Nauk; w latach 2011-2020 kierownik Zakładu Antropologii Kultury, Filmu i Sztuki Audiowizualnej w Instytucie Sztuki Polskiej Akademii Nauk; członkini redakcji „Kwartalnika Filmowego", w którym w latach 1993-2003 publikowała m.in. doroczną kronikę wydarzeń filmowych. Prace naukowe z zakresu historii oraz teorii filmu i telewizji publikowała m.in. w „Kwartalniku Filmowym” i tomach zbiorowych. Współpracowała z kwartalnikiem „Polish Culture” (1997-2015). Zasiadała w jury Międzynarodowego Festiwalu Filmów Krótkometrażowych w Lublinie (2013-2014) oraz była członkinią komisji ekspertów przy Ministrze Kultury i Dziedzictwa Narodowego (2012-2014). Członkini Polskiego Towarzystwa Badań nad Filmem i Mediami. Zajmuje się filmem dokumentalnym w kontekście hybrydowych gatunków granicznych (m.in. mockdokumentem i docusoap), historią i teorią gatunków filmowych i telewizyjnych oraz kinem austriackim. 


\section{Bibliografia}

Aufderheide, P. (2016, 28 października). Avi Mograbi: Activist and Filmmaker, Center for Media \& Social Impact, https://cmsimpact.org/documentary-independent-and-public-media/avi-mograbi/

Bittencourt, E. (2021, 17 marca). Berlinale Review: „, The First 54 Years - An Abbreviated Manual for A Military Occupation". Mubi.com. https://mubi.com/notebook/posts/berlinale-review-the-first-54-years-an-abbreviated-manual-for-a-military-occupation

Bowe, B. J. (2012). A Brain Full of Contraband: The Islamic Gonzo Writing of Michael Muhammad Knight. Literary fournalism Studies, 4 (1), ss. 91-102.

Chanan, M. (2002). August. Vertigo, 2 (3). https://www.closeupfilmcentre.com/vertigo_magazine/volume-2-issue-3-summer-2002/august/

Filiatreau, J. (1975, 23 października). Who is Raoul Duke? Courier-fournal, s. E7.

John, N. J., Sharma, P. (2020). Gonzo Journalism - An Ethnography Study, International Fournal of Science and Research, 9 (8), S. 19. DOI: 10.21275/SR20724100731

Katz, D. (2021, 9 marca). Review: , "The First 54 Years: An Abbreviated Manual for Military Occupation". https:/cineuropa.org/en/newsdetail/398603/

Miller, M. (2007). Voices Within the Siege: An Interview with Avi Mograbi. Cineaste Magazine, 32 (3). https://www.cineaste.com/summer2007/voices-within-the-siegean-interview-with-avi-mograbi

O'Rourke, P. J. (2009). Interview with Hunter S. Thompson. W: A. Thompson (red.), Ancient Gonzo Wisdom: Interviews with Hunter. New York: Da Capo Press.

Pan, S. (2016, 7 marca). Arab Docs at the Berlinale: Straddling Between Fiction and Non-Fiction. IDA Documentary Magazine. https://www.documentary.org/onlinefeature/arab-docs-berlinale-straddling-between-fiction-and-non-fiction

Raven, C. (2001, 30 października). Know Nothing About Afghanistan? Blame the Death of the Documentary. The Guardian. https:/www.theguardian.com/world/2001/oct/30/afghanistan.comment

Scheib, R. (2002, 9 lipca). „August: A Moment Before the Eruption”, Variety. https://variety.com/2002/film/reviews/august-a-moment-before-the-eruption-1200547408/

Sicinski, M. (2017, 17 marca). Gadfly in the Holy Land: the Critical Cinema of Avi Mograbi. Mubi.com. https:/mubi.com/notebook/posts/gadfly-in-the-holy-land-thecritical-cinema-of-avi-mograbi

Steen Müller, T. (2001, 1 lipca). Avi Mograbi: In Between Genres. Modern Times Review. https://www.moderntimes.review/in-between-genres/

Svetvilas, C. (2004, 30 czerwca). Hybrid Reality: When Documentary and Fiction Breed to Create a Better Truth. International Documentary Association Documentary Magazine. https:/www.documentary.org/feature/hybrid-reality-when-documentary-and-fiction-breed-create-better-truth

Thompson, H. S. (1979). Fear and Loathing in Las Vegas: A Savage Journey to the Heart of the American Dream. W: Thompson, H. S., The Great Shark Hunt: Strange Tales from a Strange Time (ss. 25-34). New York: Summit Books. 
Keywords:

Avi Mograbi; gonzo-document; author's strategy;

Israeli cinema; Israeli-Palestinian conflict; human rights

\section{Abstract \\ Beata Kosińska-Krippner Avi Mograbi: Gonzo-Documents}

Born in 1956, Avi Mograbi is considered to be one of the most important, but also most controversial Israeli filmmakers of his generation. He makes specific political films, consistently criticizing the condition of the Israeli society and the state's policy, especially towards Palestine. Making films at the intersection of fiction and facts, he developed his own, distinct poetics; his films function mainly as documents, and he himself refers to this stylistic norm, but he does it on his own terms. Mograbi experiments with both narrative and stylistic solutions. Due to the specificity of his use of the documentary, the author of the article associated the director's creative method with gonzo-journalism. The specific implementations of his strategy are analyzed on the example of selected films, shedding light on the nature of "reality" in documentaries and the way in which reality determines the creation of films and the filmmaker himself.

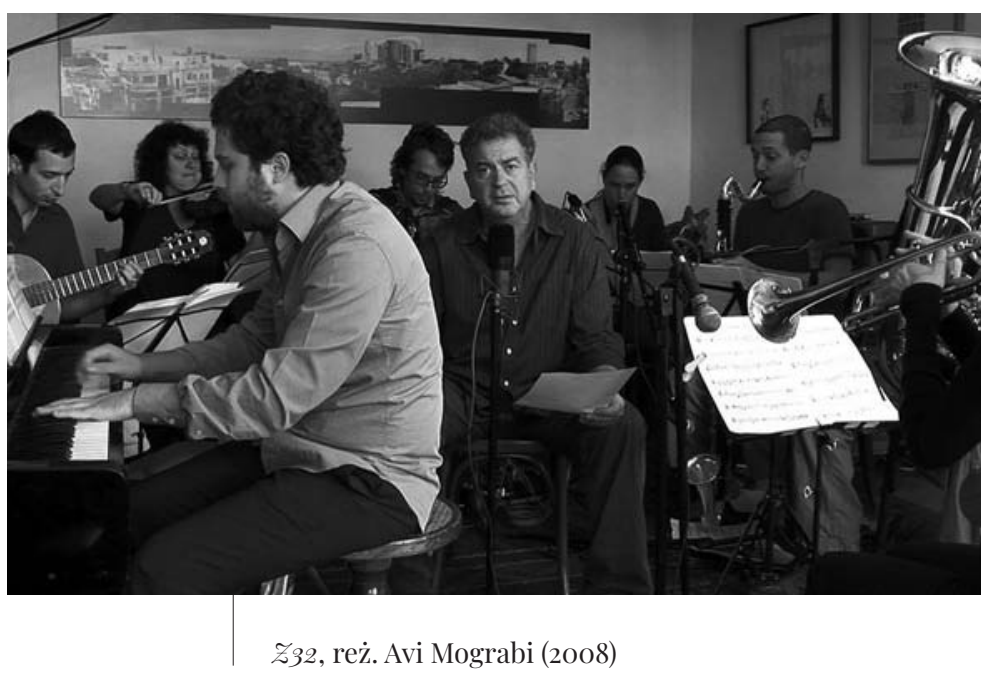

